\title{
The Glass Ceiling and Women Career Advancement: A Study Based on Ready - Made Garment Industry in Sri Lanka
}

\author{
Kuruppuarachchi K.A.P.S.T. ${ }^{1}$, Surangi H.A.K.N.S. ${ }^{2}$ \\ Department of Commerce and Financial Management, University of Kelaniya \\ sachinthanapiumi@gmail.com ${ }^{1}$, surangins@kln.ac.1k²
}

\begin{abstract}
There is a growing number of women who enter the workforce, and an increasing number of top leadership positions remain limited. This questionable situation has been identified by scholars as "glass ceiling" and researchers revealed that there are invisible barriers which women are facing when they are trying to climb up the leadership ladder. The main purpose of this study is to explore the glass ceiling concept and female career advancement in the ready-made garment industry in Sri Lanka. This study used in-depth narrative interviews and observation for data collection and eleven female employees were purposively approached and interviewed. Narratives were used to collect and analyze the qualitative data. Findings revealed that there were three main influences, namely individual barriers, organizational barriers and social barriers for women to get into the top leadership positions. The study gives some recommendations on how organizations, individuals and society can simplify the development of female advancement into the top leadership positions.
\end{abstract}

Keywords: Glass ceiling, Leadership ladder, Ready-made garments, Women's career advancement

Copyright: (C) 2019 Kuruppuarachchi K.A.P.S.T., Surangi H.A.K.N.S. This is an open access article distributed under the Creative Commons Attribution License, which permits unrestricted use, distribution, and reproduction in any medium, provided the original work is properly cited.

Correspondence: surangins@kln.ac.lk

ORCID of authors: Surangi H.A.K.N.S. : https://orcid.org/0000-0002-2671-2212

DOI: http://doi.org/10.4038/kjm.v8i2.7581 


\section{Introduction}

Participation of women is growing in professions, accompanying with males (Enid \& Singh, 2013). However, inadequate representation of women in most of the leadership roles in decisionmaking positions was the most argued topic during the past ten years. There was a critical concern about underrepresentation of women in decision - making positions in almost all the countries in the world (Helfat, Harris, \&Wolfson, 2006). According to Meyerson and Fletcher (2000), women in high business positions are still rare. As an example, there are very few females in the leadership positions such as general manager, line managers, quality managers, production managers, and head of the merchandise in some organizations of the country which are producing products and services in large scale for selling to both local and foreign buyers (Macchiavello, Menzel\& Woodruff, 2014). This doubtful situation has been pointed out in literature as "glass ceiling". Glass ceiling means an invisible higher limit in any organizations, above which it is not easy or impossible for women to be in the high ranks. It is "glass" because it's not typically a visible barrier, and a woman may not be mindful of its existence until she "hits" the barrier. In other words, it's not a clear practice of discrimination against women though specific practices, policies or attitudes that produce this barrier might exist, that produce this barrier without the intention to discriminate.

The glass ceiling concept is about invisible barriers for professional advancement for the women. It is the most powerful influence factor of difference between men and women advancement of their career ladder. This concept extensively used and highlight well - renowned media, academic publications and governments reports (Scandura, 1992; Kelleher, 1988). According to Islam and Jantan (2017), women have come from the front door of the managerial position of the organization and after they face some invisible barriers which the reasoning for their career advancement. According to the employment survey carried out by the department of labour in 2017, women in Sri Lanka represent $57 \%$ of the total estimated Sri Lankan population of 21 million. However, out of the total economically active population of 8 million, only $35.9 \%$ are women. In the Sri Lankan context, gender differences are rapidly disappeared through the formal education system in Sri Lanka (Jayaweera, 2000). According to institute of policy changes in Sri Lanka (IPS) calculation (2015), the female labour force participation increases with education. That calculation shows $83.9 \%$ high female labour participation rate with a bachelor degree, $49.9 \%$ female labour participation rate with advanced level and $29.2 \%$ female labour participation rate with ordinary level. But the rate of women advancement into the higher position in an organization is significantly low. In Sri Lanka, there is a $63.8 \%$ of female contribution to the total employment as the professionals(Labor Force Survey, 2017).It stated that, occupation group of "professionals" as the middle-level positions in some different industries, but $35.2 \%$ contribution of female to the total employment as the managers, senior officials, and legislators (Labor Force Survey, 2017). There is a growing number of women who enter the workforce, and but increasing number of top leadership positions remain limited (Eagly \& Carli, 2003). Empirical studies on this questionable 
situation have pointed out as "Glass ceiling". It shows that there are invisible barriers which women are facing when they are trying to climb up the leadership ladder.

While initially glass ceiling studies were mainly considered with the failure of women in getting the senior and executive positions, it was essential to focus on examining the reasons for inequality within management positions and career paths. Now, an important question arises: how culture, context influence towards the glass ceiling concept? To answer this question, authors must consider the level of culture manifestation or its appearance, which is the level of social behaviors in specific contexts For example, western countries can be identified to have barriers for female employees to enter in the leadership position in the organizations with their industrial perspectives, whereas Asian cultures focus on individual barriers. In this setting, the purpose of the study is to explore the influences of the glass ceiling faced by women in the readymade garment industry where significant numbers of female employees are engaging in different positions. This particular industry is selected because women are considered as the second key foreign earner for Sri Lanka who is working in ready-made garment industry. According to the annual survey of industries (2017), 85\% of workers in the ready-made garment industry are women, and it is a female dominated industry. In this Industry, There is a significant percentage of women employees who are in middle level positions up to a certain extent. (Annual survey of industries, 2017)

\section{Literature Review}

The set of barriers that prevent women from advancement into top-level positions have created an invisible glass ceiling which is problematic for women to break. The situation is discussed as a "ceiling" as there is a restriction of upward advancement and "glass" (transparent), because the restrictions are not directly apparent. Therefore, they are commonly coming in an unwritten and unofficial way. The term was invented by Ann Morrison in the 1980s. According to Morrison (1980), Glass ceiling is to unseen barriers or obstructions that create steeplechases for women and other minorities from growing to the top-level leadership positions.

This phenomenon was used for the very first time in 1986 by the "Wall Street" which comes under American newspaper, which is a special report on women in the corporate world (Hymowitz \& Schellhardt, 1986). It was used to narrate the business world where entered to top levels of leadership for women was hindered by corporate heritages and biases. Since the declaration of this article, the phenomenon "glass ceiling" is used to represent the invisible barriers that protect women from climbing to top levels of leadership positions(Morrison, White \& Van Velsor, 1987; Lyness \& Thompson, 1997; Davidson \& Cooper, 1992; Cooper, 2001). The conclusion of the study by Morrison et al. (1987) described about few true differences between men and women based on psychological, emotional, or intellectual qualities. However, the study stated that three limitations in the expectations for women were a major factor which caused the glass ceiling. The first limitation is that women were expected to be strong but not display manly characteristics. The second limitation is that they were expected to 
take duties and responsibilities yet be compliant in following orders and the last limitation is that they were expected to be pushy yet not to expect equal treatment. Morrison and colleagues also described that the "glass ceiling" applied to women as a group, not just individuals.

The phenomenon of 'glass ceiling' shows the invisible artificial barriers, created by personal attitudes and organizational biases which block women executives from top-level management positions (Wirth, 2004). According to Wirth (2004), Talented and skilled women can view what they are capable of achieving, but these glass ceilings restrict them from achieving the desired top positions. Glass ceiling at the workplace is basically an indication of economic and social gender inequalities. It describes the situation where there is no objective answer to the logical question- why women are not growing to the higher management positions like as men do. It states at the natural inequality in the procedures and structures of both organizations and society in general. The glass ceiling is generally represented by a pyramidal shape and may be present at different levels from junior to top levels depending on organizational hierarchy.



Figure 1 The glass ceiling in the organization pyramid (Wirth, 2004)

The Gender Organization System (GOS) introduce a holistic tool to study the problems relative to the women's advancement into the top leadership positions (Omor \& Davidson, 2001; Akpinar Sposito, 2013).That is, when researchers are trying to determine why women have had narrow success making it into the top levels, they should try to identify die characteristics of the organization context, the characteristics of the social system as well as characteristics of the individuals, as an example their gender, which could potentially be affecting women's and men's attitudes This approach stated law participation rate of females in top positions is the result of the concurrent interaction between the individual, organization and society (Fagenson, 1993; Yukongdi \& Benson, 2005). To identify the gender inequality in the particular organisations, it is not only the finding of a barrier to the betterment of women into top leadership levels but also organizational culture and their structural behaviour which are main factors creating women inequality in the organizations.

Three tools may describe the glass ceiling term through biological models, 
socialization models, and structural/cultural models (Cleveland et al., 2000; Bartol, 2003; Weyer, 2007). According to biological models, this theory stated there are some biological differences between men and women, such as genetic, hormonal, and physical characteristics, and the results for these differences are the reason of genetic design developed from conversions to differing reproductive situations of past males and females. These conversions have appeared slowly over thousands of generations, and these dissimilarities are stable and required for survival (Cleveland et al., 2000; Lueptow et al., 2001). Socialization approach focus on seeing differences between men and women. The approach assumes that there are differences in the behaviors can be shown between men and women under various social and pattern of thinking development processes of the particular persons related with their life cycles stages, such as schooling and working life. Under the structuralcultural models, there are systems, social structures, and arrangements described as gender differences due to dissimilarity in position and power (Bartol, 2003).

The human capital model describes the existence of the glass ceiling through differences in individual choices that women make based on their personal differences. According to Human Capital Theory (Becker, 1964), the differences in education, work experience, skills and qualification make different individual choices with relevant to career advancement for women.

Glass- Ceiling is a myth and selfcreated issue

According to Rai and Srivastava (2008), they argue there is no glass ceiling happens. Moreover, they say that at current organizations operate globally, there is number of opportunities for carrier development. It is just a myth and self-created issue. Their first argument is that women can catch top positions based on their capabilities, through their commitment, hard work and aspirations. Their second argument is family tasks come into the middle part of the carrier development.

According to Mainiero \& Sullivan (2005), women have shown a vast development in achieving access to organizations and destroying the glass ceiling. Despite such successes, the majority of women still, stay stuck in middle management positions. The problem of the glass ceiling continues to grow though there is no clear difficulty which keeps women out of the professional growth competition and acquiring advanced job positions. All the cooperate level organizations are giving an equal chances for employees in the recruitment process as there are no any advertisement states "minorities or women are not eligible to apply".

Empirical studies say globalization has created massive oppoetunities for career advancement. (Blau, 2006). Women give more priority to their families than men and prepare a more indirect course of action for their professions. That is the main reason for investing in education and training become less useful for women apart from the knowledge gained, and it has become out of fashion in career breaks. (Schneer \& Reitman, 2002). Family structure creates a large impact on women's success in career life and responsibilities of their children and home increase their stress level. (Polachek ,1981). 
According to Browne and Meyer (2003), the truth of the glass ceiling is unclear and they suggested that the looking glass is the most suitable metaphor for some people than the glass ceiling. They highlighted the importance of employee-employer relationship above all strategies to deal with the complex nature of visible and invisible barriers in order to advance organizations once identified by individual or group of managers.

\section{Barriers for glass ceilings}

Individual barriers are the level to which individual reasons which are imminent from themselves and affect their career advancement (Bombuwela,2013). And also, if women lack skills, basic traits and attitudes to prosper in top positions, then they require some motivation and self-confidence which are serious qualities for clutch the top positions in an organization (Singh \&Teresian 2008). As defined by the Smith, Crittenden and Caputi (2012) behavior of women are supportive, nurturant, caring and concerned when men are self-confident, pushy, independent and powerful which are extremely significant to catching the top position. As stated by the Bombuwela and De Alwis (2013) individual barrier is the most persuasive factors for female career advancement. The findings specify that male foils were visibly appealing in social networking actions than the female counter foils while achieving top positions in the organization, because of that men become even more visible than their female foils, (Kiaye \& Singh 2013). Therefore, Edirisinghe and Thalgaspitiya (2016) state that there is a seriously high positive correlation between the individual barrier and the glass ceiling effect. Worrall et al.
(2010) drawn that lack of confidence and sureness negative assertiveness affected female career advancement. According to Cross (2010), thirteen out of the thirty participants specify that they want to attain top management in the short term ,but individual barriers chunk their career advancement.

Women's scareer advancement is beaten by organizational structure and practices (Tlaiss \& Kauser, 2010). Tlaiss and Kauser (2010) moreover define human resource practices, organizational culture, organizational and organizational networks, interpersonal relations, role modelling and minimum effort identified as a factor of the organizational barrier. Furthermore, lack of opportunity to participate in professional development, occupying inadequate recruitment practices, inhabiting staff versus line positions, a lack of understanding, commitment, equal employment opportunity principles, the culture of an organization (Myers, 2010), transparency in promotion process and culture of lengthy working hours (Cross 2010), values in performance evaluation (Johns, 2013), are also coming under the pointers of the organizational barrier. According to the research findings of empirical studies, total of 72 percent of the female employees stated organizational barriers such as the organizational culture being male-oriented and not caring about female requirements.(Ismail \& Ibrahim, 2008).

Societal blocks are in the barriers which come from the culture and civic policy. Contributing features which are arising from the social to the blocked career advancement for women; such as some features of social curricula and strategy, restricted human capital and the societal belief of female contribution in some industries (Eagly \& Sczesny, 2009). 
According to Rapport et al. (2002), and True et al. (2012), there is a strong societal bias in the South Asian (and even in Western) countries when men are naturally born as leaders and the female figure is considered as a household worker and sex slave.. Men are naturally raised up to be violent and autonomous when women are raised up to be more dependent. A woman's key responsibility is at home /household work, and a man's key responsibility is at work. Child-care, home managing and domestic forming are the main responsibilities of a women. According to Biological, Social and Structural/Cultural Model, the "glass ceiling" phenomenon emphasis on the experimental changes between men and women. According to this factor, men and women act otherwise because of the dissimilar courses of social and mental progress of the individual connected to their life phases, like education and work.

Female career advancement and the glass ceiling in Sri Lanka

In the development of technology, globalization and liberal business environment in Sri Lanka, and the arrival of women into the labour market, more opportunities were created for Sri Lankan women to reach management positions. the importance of government policies such as free education and higher studies are the reasons for these changes. However, at the end of the year 2017, the advancement of women in decision making at various levels in public and private sector is very low, and the women in the highest management levels have increased only by 20 percent. Still, in 2017, managerial job opportunities are not being equally distributed among males and female (The Department of Census and Statistics, 2017)
Female Career advancement is a concept that discusses about how women climb up the ladder to receive a new position. (Rosenfeld \& Jones, 1987) .Out of 198 directors in 25 top Corporates in Sri Lanka, there are only 10 women represent it (Sri Lanka directors institute, 2017). Research also shows that more investment fund companies are including gender diversity indicators among their criteria for a move that suggests investor selfconfidence may improve with the adding of women to a company's board. However, Bombuwela and Chamuru (2013) stated, the glass ceiling has 27.4 $\%$ influences on the women career advancement among the female middlelevel employees working in the private sector organization in Sri Lanka. And also, it is clearly said that other factors have $72.6 \%$ influences on female career advancement. Jayathilaka (2016), stated cultural, situational and personal factors have affected the problem of female career advancement and there is still a need to the motivation for equal representation of women in executive management positions in both public and private sector. The organizational culture is a major barrier to women's advancement into senior management, and organizational culture has changed to encourage the women's participation in managerial positions. In the same way, they agreed on the occupied organizational environment, commitment to the careers, managing with new technology, negative insight and categorizes, lack of support by people, pay attention to say at meetings, and organizational encourage women for leadership positions as main barriers as situational factors. Therefore, the cultural, situational and personal factors do not impact the managerial effectiveness of women managers, and 
they have better managerial effectiveness (Jayathilaka, 2016).

\section{Methodology}

A qualitative approach was chosen as the methodology of this study because this approach supports an understanding and explanation of meaning underlying human interaction such as a view of women future career life and how it links with different influences. A qualitative study has its highlighted logical hypothesis as the view that 'reality is constructed by individuals interacting with their social world'.

The sample for the study is experienced middle-level female employees in readymade garments in Biyagama export processing, Sri Lanka. The Biyagama export zone is the second zone of the board of investment to be reputable. The Zone employees total 21,136 and host 57 businesses. Of these 18 are in the Apparel sector. In this 18 companies represent more than $80 \%$ female labour force participation, and out of this female participation, $40 \%$ represent middle-level positions such as general manager, line managers, quality managers, production managers, head of the merchandise (BOI, 2010).The sample was a purposefully selected group of middle-level female employees of Biyagama ready-made garment industry in Sri Lanka . After reaching the saturation point, the researcher identified sample size is eleven.

In-depth narrative interviews and observation were used to collect data. The thoughts were adhesively recorded and then transcribed. Patton (1990) stated that a tape recorder is "crucial". The researcher stated on a tape recording the discussions to allow for methodically and in-depth searching without the disturbance of note taking (Sanders, 1982).

The ultimate goal of this qualitative methodological study was to define the "glass ceiling" concept in experience middle-level female employee in the ready-made garment industry in Sri Lanka. To achieve that, the researcher used the following phases to analyze the data:

1. Transcripts were read and again reread while noting to audio recordings of the interviews.

2. A line-by-line analysis of the written transcript was directed to disclose the meaning of the glass ceiling phenomena and highlighted the important sentences, statements or quotes that provided an understanding of how the interview participants experienced with the phenomenon of the glass ceiling and allocated some memorable codes to each of the significant sentences, statements, or quotes.

3. Developed bunches of understanding from the important codes or descriptions into themes (Creswell, 2007). The themes were shaped by categorizing units of meaning together (Creswell, 1998; Moustakas, 1994). Researcher wrote an explanation of what are the interviewed participant experienced or idea with the phenomenon of a glass ceiling (text description) for each and every theme. Subthemes were also recognized under the main themes. These steps were tracked according to a methodical process that stimulated from narrow sets of analysis (e.g. significant statement or codes), on to broader sets (e.g., meaning units/sets), and on to detail/meaning descriptions that review two basics, "what" the interview individuals have experienced and 
"how" they have experienced it (Moustakas, 1994).

4. A developing model was established to explain the relationship between identified themes and research questions.

5. All findings were shared with interview participants for member checking as well as peers for review to ensure the trustworthiness of the data.

In qualitative studies, the researcher should address the trustworthiness and validity of the study by exploratory the credibility, transferability, and dependability of the findings (Miles \&Huberman, 1984). Creswell (2009) and Merriam (2002) recognized various approaches to support a qualitative study's internal validity. Triangulation, peer review and member checks methods were used. Triangulation in this study can be identified through observation and conversation. The researcher kept a publish reports statistics and field notes during the research process and consume this as a supportive resource throughout the data analysis stage of the study. Peer reviewing is an approached consumed when peers read and comment on the findings. The researcher used two associated colleagues in the University of Kelaniya as peer reviewers for this research. Member checking includes pleasing data, explanations, and conclusions back to the participants' individual for their comment on the truth and the complete approval of the information (Esterberg, 2002; Merriam, 2002).Regarding the ethical side of the research, an ethical procedure was followed throughout the research process.

Findings and Discussion: Themes derived from women's Narratives
Three major themes and nine subthemes derived from the women stories.

\section{Individual Barriers}

\section{Lack of higher educational background}

Education can be defined as the selfenlightening process and also an important component of career. It supports to make a clear picture of everything around the working environment. According to this research, the sample was experiencing middle-level female employees in the ready-made garment industry in Sri Lanka, and they already have education level which matches their current middle-level position. However, lack of higher education which is required for the top-level position is creating some big problem for such middle-level female employees when climbing the career ladder. In this study, higher education means every kind of higher studies which are required to the toplevel position such as professional education or academic education.

"In order to climb in the ladder of the career, should earn higher educational or professional experience as well as working experience, cause our company encourages the women empowerment, under the most of the top management are held by women and $75 \%$ of the staff are women in our organization. At still up to now, I am not able to find suitable higher studies path for my career, and it is a big disadvantage for me." (E)

\section{Self-Rejection}

Women start their careers with motivations that are just as high as their male colleagues. However, before they achieve their top-level career goals and shy away from challenging for these 
jobs. The reason is that women are risk opposed or lack of sureness/confidence, or maybe because they have different career preferences.

"I refused to accept the responsibility of top position in my own hands. Cause I often have to go abroad for my sporting activities and I have to get leave frequently, that's why I made that decision" $(G)$

Same evidence but the different reason was found in K's story,

"I was provided with the opportunity to go to a higher position. But I did not want to go to the place. When losing my colleagues in here. I'm scared to go to work there. Therefore, I felt that I could not fulfill the responsibilities of that position that's why I reject that position." $(K)$

\section{Family problems}

Family responsibilities are one significant factor affecting the number of period and energy that women are able and willing to dedicate to work. The difficulties of the family have been shown to decrease women's individual resources of time, energy, and commitment available for work. Seven out of the eleven interview participants drawn that the present individual family schedules have disadvantaged their career life. Following evident is proof that:

"I am married, and my husband is in Kandy, and I'm in Colombo. I am going home the only weekend. Job and family management is very difficult. There are some career disadvantages due to the lack of participating in some training during the weekend" (H)

"Because of my mother's role, I had to avoid certain jobs responsibilities of the top level. Naturally, my mother-in-law refused my work" (I)

\section{Organizational Barriers}

Lack of work colleagues and top management support

For women to climbed career ladder equally in business life, the role of the top management team and work colleagues support is important. The Lack of support will create major pressure for women, and it creates the obstacle to gain top-level management position. Interview participants were drawn that the present lack of work colleagues and top management support have disadvantaged their career life. Following evident is proof that:

"People who are serving with me and talking to some of the lasses I missed many opportunities for my career advancements" $(F)$

"People who are eating with me create some Snitch for my career advancement" (I)

\section{Sexual harassment}

Sexual harassment is named as a term of sex discernment below the title seven of the civil rights act of 1964 . Uninvited sexual developments, requirements for sexual favoritism, and other oral or bodily conduct of a sexual environment that affects individual women employment or work performance of women (U.S. EEOC 2011). Sexual harassment is enclosed in the workplace when it occurs: at work, at work-related events or practices or where people are carrying out work-related roles between people allocation the similar workplace. Some of the interview participants outlined that the sexual harassment pressure has an obstacle for their career ladder in the ready-made garment 
industry; this is evident in the following statement:

"There was kind of harassment for getting fulfilled their sexual needs. Always benefits were increased according to their that kind of favor. At that time, I was in the Secretary's position when I objected that request; my position fell in two directions "(D)

\section{Gender discrimination}

More open-minded organizations are starting to understand more about dissimilarity problems by examining gender combinations at various organization stages such as leadership programs as well as on training and development programs, selecting candidates for top managerial and leadership positions and attracting people on new opportunities and elasticity projects. Interview participants were drawn that the present gender discrimination situation has disadvantaged their career life. Following evident is proof that:

"As an example, I mean top level management has to travel some long distant plant for our office purposes. our management does not recruit women for such position, because they believe women raise some big problems like as sanitary cases, motherhood cases, husband or family cases etc. They only recruit males for that executive position." (A)

\section{Societal Barriers}

\section{Social environment pressure}

The social environment includes all types of social relationships and groups such as, religion, educational, technological, cultural, entertaining, residential and financial group shaped by women with her environment.
Pressure from these groups limited to female career advancement because the anxiety of rejection in a social environment will be decreasing Female career advancement. Interviewed participants were drawn that the present social environment pressure has made a disadvantageous impact on their career life. Following evidence prove that:

"Sometimes it is too late to get home from after the work. In such cases, some of my neighbours and relatives are accusing me I am not a good mother" $(F)$

\section{Matter of the gender}

Matter of gender means difference behavior expected from an ideal woman. Matter of gender affects a wide variety of career outcomes, career behaviours and career attitudes. This contains occupational fitness, career select, work attitudes, career knowledge, other people's insights, and career results. Interviewed participants were drawn that the present matter of gender has caused disadvantages their career life. Following evidence prove that:

"The social opinion that a guy should be in this position and lady cannot reach that. The society said you did little job and didn't go to the biggest places, it is not matched with you, because you are a lady" (J)

$\underline{\text { Sri Lankan cultural background. }}$ 
In Sri Lankan context, traditional norms, religious opinions, beliefs, values related to women's occupations specifically, when they are associations with the outside party make an obstacle for their career development. They basically surface various experiences, and opportunities in their social roles compared to men due to social expectations family constraints, marital status, motherhood, and career difficulties. Unluckily these factors are still continued to grow in Sri Lanka and have a huge effect on women in most parts of our cultures. identify their key skills thus, they do not believe in their abilities, skills and talent" (C)

Based on the findings, the model was introduced by the researcher (Figure 2).

Individual Barriers

- Lack of higher education background

- Self-Rejection

- Financial problem

- Family Problems

\section{Organizational Barriers}

- Lack of work colleagues and top management support

- Sexual harassment

- Gender discrimination

\section{Societal Barriers}

- Social environment pressure

- Matter of gender

- Sri Lankan cultural background

Figure 2 A model of the glass ceiling concept and female career advancement in ready-made garment industry in Sri Lanka (Source: Research Model

According to C's opinion Sri Lankan religion belief has become a barrier for her career,

"Culture of the South Asian Countries especially the SL culture has created a trend that the women should stay at home, especially in my context because I'm a Muslim and women often do not 


\section{Conclusion}

The main purpose of this study was to explore the glass ceiling effect for female employees to access into the leadership positions in ready-made garments industry in Sri Lanka. The study revealed that three major influences such as individual, organizational and societal as the important barriers for the female employees to get access in the leadership positions in ready-made garments industries in Sri Lanka. Firstly, individual barriers are the most common barriers faced by women when they reach to top leadership positions. Lack of higher education, self rejection and family problems were identified as individual factors. Secondly, under the theme of organizational factors, women revealed that lack of work colleagues and top management support leads to, sexual harassment and gender discrimination as main barriers in their organizations. The third societal barrier has been a major concern that has obstructed the advancement of women's career. According to the sample, social pressure, a matter of gender and Sri Lankan cultural background were the main barriers.

This study result would be supportive of women in middle-management positions in the ready-made garment industry who need to advance their career to a senior level management position. When there is a bulky amount of research led regarding the "glass ceiling" phenomenon, the vast has been intensive on country wise or sector wise with little intensive of industrial wise (ready-made garment). Many studies have confirmed that there are individual barriers which limit women's career growth but, in this study, also find another two barriers called organizational and societal.

Therefore, findings of this study contribute to an in-depth understanding of women's achievements as top management positions at the readymade garments industry in Sri Lanka. The findings can be used to the particular industry for rearrangement the organizational leadership hierarchy which makes an important influence on the organizational better performances. Men, as well as women from all who are working ready-made garments, may benefit from the study because the findings are a help to become successful as a leader and can be applied and can be transferred to other fields also. Findings can be a generalization of other fields also in the Sri Lankan context. Inspiring and helping more women to track senior-level leadership positions helps resolve the problem of low representation of women leadership in ready-made garment industry

According to research results among the glass ceiling influences, one of the major influences is the individual barrier. From now on female employees, as well as women empowerment organization, must work to avoid the individual barriers such as, lack of the higher education, lack of finances for education and lack of selfconfidence and being too emotional when associating with the family. As an example, to avoid the family problems organization party can support the women employees by sending women off on weekends, providing day care centers, giving some stretchy hours in the office. Some can say that sending women off on weekends will affect organization performance. However, to gain the highest input of the female 
capacity, the brilliant organization must give something for them and expect something from them. Therefore, to avoid the lack of financial barrier to higher education, the organization can provide some reasonable loans for educational purpose with minimum interest or null interest. Finally, women must build their own self-confidence as well as self-respect, independence and own talent to avoid their individual barriers which affect their career advancement.

Most of the female employees of the sample did not approve of the quality of the environment of the organization. Hereafter top management must handle the human resource in a fair manner. It is acceptable to offer the same rights and responsibilities to male and female workers within the organization as such same wages according to the experience and knowledge level; the same advancement applies the same work responsibilities. Also, an organization can have some programs to change the worker's insights of the female employees management and to make the good network among work colleagues and senior management, because majority of the interview participants did not agree with the equal treatment of the management. Moreover, management should be aware of a different kind of harassment like sexual harassment. Likewise, to allow women who are in engagement to progress their careers, the organization could provide the training and other career advancement instruments that will also help to modify their arrogant behavior about the organization to a positive side.

As the respondents, stated other influential glass ceiling factor is societal factors. Here most prevailing barrier is gender stereotyping, pressure from social associates and Sri Lankan culture. To avoid that barrier, the attitudes of others concerning traditional myth that women are homemakers, sex figure and they cannot work as males should be eradicated. Sri Lankan cultural background should be changed like developed countries because those cultures did not put barriers on female career advancement. It is not an easy task under the Sri Lankan context. However, the Sri Lankan government must inspire female entrance in all professional areas through strategy modifications and the quota scheme for breaking the cultural barrier.

\section{Reference}

Acker, J. (2009). From the glass ceiling to inequality regimes. Sociologie dutravail,51(2),199-217.

Akpinar Sposito, C. (2013). Women in management research: Theoretical perspectives. Le 24eme FrancoTcheque. Trends in International Business, 11.

Akpinar-Sposito, C. (2013). Career barriers for women executives and the Glass ceiling Syndrome: the case study comparison between French and Turkish women executives. ProcediaSocial and Behavioral Sciences, 75, 488-497.

Anderson, D. R. (2005).The importance of mentoring programs to women's career advancement in biotechnology. Journal of Career Development, 32(1), 60-73.

Annual survey of industries (2017).Annual Survey of Industries Final Report 2016. Retrieve from http://www.statistics.gov.lk/industry/A SI 2016 Report.pdf. 
Arun, K., \& Lawrence, W. (2018).A Study on the Impact of Women as a Diversifier in Hospitality and Tourism Industry-An Economic Game Changer. Indian Journal of Public Health Research \& Development, 9(2).

Auster, E. R. (2001). Professional women's midcareer satisfaction: Toward an explanatory framework. Sex Roles, 44(11-12), 719-750.

Babbie, E., \& Mouton, J. (2001).The ethics and politics of social research. The practice of social research.

Bartol, K. M., Martin, D. C., \&Kromkowski, J. A. (2003). Leadership and the glass ceiling: Gender and ethnic group influences on leader behaviors at middle and executive managerial levels. Journal of Leadership \& Organizational Studies, 9(3), 8-19.

Baugher, S. L., \& Martin, B. B. (1981).Women in the Administrative Marketplace. Viewpoints in Teaching and learning, 57(4), 79-85.

Becker, G. (1964). human capital, NY. GS Becker.

Benson, J., \&Yukongdi, V. (Eds.).(2006). Women in Asian management.Routledge.

Blau, F. D., \& Kahn, L. M. (2006). The US gender pay gap in the 1990s: Slowing convergence. ILR Review, 60(1), 45-66.

Brannen, J. (2017). Mixing methods: Qualitative and quantitative research.Routledge.

Browne, M. N., \&Giampetro-Meyer, A. (2003). Many paths to justice: The glass ceiling, the looking glass, and strategies for getting to the other side. Hofstra Lab. \& Emp. LJ, 21, 61.

Bryman, A. (2006). Integrating quantitative and qualitative research: how is it done? Qualitative research, 6(1), 97-113.

Burns, N., \& Grove, S. K. (1993).The practice of nursing research. Conduct, critique \& utilization, 4(5).

Caligiuri, P. M., \& Tung, R. L. (1999).Comparing the success of male and female expatriates from a US-based multinational company. International Journal of human resource management, 10(5), 763-782.

Carli, L. L., \&Eagly, A. H. (2016). Women face a labyrinth: An examination of metaphors for women leaders. Gender in Management: An International Journal, 31(8), 514-527.

Carr, P. L., Szalacha, L., Barnett, R., Caswell, C., \& Inui, T. (2003). A" ton of feathers": gender discrimination in academic medical careers and how to manage it. Journal of women's health, 12(10), 1009-1018.

Central Bank of Sri Lanka.(2017). Annual Report 2017. Retrieved from https://www.cbsl.gov.lk/en/publication s/economic-and-financialreports/annual-reports/annual-report2017

Chaudhuri, P. (2010). Sexual harassment of women health workers. Health providers in India on the frontlines of change. New Delhi: Routledge, 223-41.

Chawla, S., \& Sharma, R. R. (2016). How women traverse an upward journey in Indian industry: multiple case studies. Gender in Management: An International Journal, 31(3), 181206. 
Chou, W. C. G., Fosh, P., \& Foster, D. (2005). Female managers in Taiwan: Opportunities and barriers in changing times. Asia Pacific Business Review, 11(2), 251-266.

Chou, W. C. G., Fosh, P., \& Foster, D. (2005). Female managers in Taiwan: Opportunities and barriers in changing times. Asia Pacific Business Review, 11(2), 251-266.

Christine Cross, (2010) "Barriers to the executive suite: evidence from Ireland", Leadership \& Organization Development Journal, Vol. 31 Issue: 2, pp.104-119

Civil Right Act 1996.H.R.3748 - Civil Rights Procedures Protection Act of 1996. Retrieve from https://www.congress.gov/bill/104thcongress/house-bill/3748.

Cleveland, J. N., Stockdale, M., Murphy, K. R., \&Gutek, B. A. (2000). Women and men in organizations: Sex and gender issues at work. Psychology Press.

Cooper Jackson, J. (2001). Women middle managers' perception of the glass ceiling. Women in management review, 16(1), 30-41.

Corbin, J., Strauss, A., \& Strauss, A. L. (2014). Basics of qualitative research.

Cotter, D. A., Hermsen, J. M., Ovadia, S., \&Vanneman, R. (2001). The glass ceiling effect. Social forces, 80(2), 655681 .

Creswell, J. W. (1998). Qualitative inquiry and research design: Choosing among five tradition.

Creswell, J. W. (2002). Educational research: Planning, conducting, and evaluating quantitative (pp. 146-166). Upper Saddle River, NJ: Prentice Hall.
Creswell, J. W. (2009). Mapping the field of mixed methods research.

Creswell, J. W., Plano Clark, V. L., Gutmann, M. L., \& Hanson, W. E. (2003). Advanced mixed methods research designs. Handbook of mixed methods in social and behavioral research, 209, 240.

Cross, C. (2010). Barriers to the executive suite: evidence from Ireland. Leadership \& Organization Development Journal, 31(2), 104-119.

Currie, J., \& Thiele, B. (2001). Globalization and gendered work cultures in universities. Gender and the restructured university, 90-115.

Davidson, M. J., \& Cooper, C. L. (1992). Shattering the glass ceiling: The woman manager.Paul Chapman Publishing.

Davidson, M.J. \& Cooper, C.L. (1992).Shattering the glass ceiling.The woman manager, Paul Chapman, London

De Alwis, A. C., \&Bombuwela, P. M. (2013). Effects of glass ceiling on women career development in private sector organizations-Case of Sri Lanka.

Denzin, N. K., \& Lincoln, Y. S. (Eds.).(2011). The SAGE handbook of qualitative research.

Department of Census and Statistics (DCS) (2017), Census of Population and Labor Force Survey, Colombo.

Devadas, U. M., \& Silva, A. P. (2017).Underrepresentation of Women in Leadership in Sri Lanka.In Current Perspectives on Asian Women in Leadership (pp. 139-159). Palgrave Macmillan, Cham. 
Doherty, L., \&Manfredi, S. (2010). Improving women's representation in senior positions in universities. Employee Relations, 32(2), 138-155.

Dollija, E., Theodhori, O., \&Çollaku, M. An empirical analysis of the barriers faced by women managers in albanian banking sector.

Dost, M. K. B., \& Tariq, S. (2012). The Organizations having high level of glass ceiling, has lower productivity due to lack of employee commitment. Kuwait Chapter of the Arabian Journal of Business and Management Review, 1(8), 93.

Eagly, A. H., \& Carli, L. L. (2003). The female leadership advantage: An evaluation of the evidence. The leadership quarterly, 14(6), 807-834.

Eagly, A. H., \&Sczesny, S. (2009). Stereotypes about women, men, and leaders: Have times changed?.American Psychological Association.

Eagly, A. H., Makhijani, M. G., \&Klonsky, B. G. (1992). Gender and the evaluation of leaders: A metaanalysis.

bulletin, 111(1), 3 .

Psychological

Edirisinghe, C. L., \&Thalgaspitiya, U. K. (2016).Investigation of Barriers on Glass ceiling Effect among Female Executive Employees in a Selected Large Apparel Industry in Sri Lanka.

England, P., Farkas, G., Kilbourne, B. S., \& Dou, T. (1988).Explaining occupational sex segregation and wages: Findings from a model with fixed effects. American Sociological Review, 544-558.

Enid Kiaye, R., \&Maniraj Singh, A. (2013). The glass ceiling: a perspective of women working in Durban. Gender in Management: An international journal, 28(1), 28-42.

Esterberg, K. G. (2002). Qualitative methods in social research.

Fagenson, E.A. (1990a). At the heart of women in management research: Theoretical and methodological approaches and their biases. Journal of Business Ethics, 9, 267-274.

Fagenson, E.A. (1993). Women in management: Trends, issues and challenges in managerial diversity. Newbury Park, CA: Sage Publications.

Fetters, M. D., Curry, L. A., \& Creswell, J. W. (2013). Achieving integration in mixed methods designsprinciples and practices. Health services research, 48(6pt2), 2134-2156.

Firestone, W. A. (1987). Meaning in method: The rhetoric of quantitative and qualitative research. Educational researcher, 16(7), 16-21.

Firestone, W. A. (1993). Alternative arguments for generalizing from data as applied to qualitative research. Educational researcher, 22(4), 16-23.

Gelman, A., Stern, H. S., Carlin, J. B., Dunson, D. B., Vehtari, A., \& Rubin, D. B. (2013). Bayesian data analysis.Chapman and Hall/CRC.

GESTIN, F. (1991). UN PAYSAGE. Etudes rurales, 121(121124), 73-89.

Goodman, J. S., Fields, D. L., \& Blum, T. C. (2003). Cracks in the glass ceiling: In what kinds of organizations do women make it to the top? Group \& Organization Management, 28(4), 475501. 
Gunawardena, C., \&Lekamge, D. (2002). Men and Women in Leadership Roles: A Study of the Open University of Sri Lanka. In 8th National Convention on Women's Studies, Colombo.

Gupta, A., Koshal, M., \&Koshal, R. K. (2006). Women managers in India: Challenges and opportunities. Management in India, 285-312

Hall, R. M., \& Sandler, B. R. (1984). Out of the Classroom: A Chilly Campus Climate for Women?.

Helfat, C. E., Harris, D., \&Wolfson, P. J. (2006). The pipeline to the top: Women and men in the top executive ranks of US corporations. Academy of Management Perspectives, 20(4), 4264.

Hodges, J. (2017). Cracking the walls of leadership: women in Saudi Arabia. Gender in management: an international journal, 32(1), 34-46.

Holst, E. (2006). Women in managerial positions in Europe: Focus on Germany. management Revue, 122$142 .$.

Hymowitz, C., \&Schellhardt, T. D. (1986). The glass ceiling: Why women can't seem to break the invisible barrier that blocks them from the top jobs. The Wall Street Journal, 24(1), 1573-1592.

Ibarra, H., Ely, R., \& Kolb, D. (2013). Women rising: The unseen barriers. Harvard business review, 91(9), 60-66.

Institute of Policy Studies of Sri Lanka.IPS Calculation 2017.Retrieved from IPS Publicationhttp://www.ips.lk/publications/governa nce-series.
Isaac, S., \& Michael, W. B. (1971). Handbook in Research and Evaluation: A Collection of Principles, Methods, and Strategies Useful in the Planniing, Design, and Evaluation of Studies in Education and the Behavioral Sciences. EdITS.

Islam, M. A. (2018). Factors Influencing Female Progression in Leadership Positions in the ReadyMade Garment (RMG) Industry in Bangladesh. Journal of International Business and Management, 1(1), 1-13.

Islam, M. A., \&Jantan, A. H. (2017). The Glass ceiling: Career Barriers for Female Employees in the Ready Made Garments (Rmg) Industry of Bangladesh. Academy of Strategic Management Journal, 16(3), 1-11.

Ismail, M., \& Ibrahim, M. (2008). Barriers to career progression faced by women: Evidence from a Malaysian multinational oil company. Gender in Management: An International Journal, 23(1), 51-66.

Jayatilake, L. V. (2016). Women managers and their perceived barriers for upward mobility in public and private sectors with special reference to the selected services in Sri Lanka. International Journal of Scientific Research and Innovative Technology, 3(2), 64-77.

Jayawardena, D. Looking Through the Glass of Managerial Femininity. Polemic, 1(01), 1-13.

Kang, H. R., \& Rowley, C. (2005). Women in management in South Korea: Advancement or retrenchment? Asia Pacific business review, 11(2), 213231.

LaborDemandSurvey2017.Retrievefro mhttp://www.statistics.gov.lk/industry/ 
Labour_Demand_Survey_2017_Report .pdf.

Lathabhavan, R., \&Balasubramanian, S. A. (2017). Glass ceiling and women employees in Asian organizations: A tri-decadal review. Asia-Pacific Journal of Business Administration, 9(3), 232246.

Lichtman, M. (2006). Qualitative research in education: A user's guide. London: Sage Publications.

Lincoln, Y. S., \&Guba, E. G. (1985). Naturalistic inquiry (Vol. 75).Sage.

Liz Doherty, SimonettaManfredi, (2010) "Improving women's representation in senior positions in universities", Employee Relations, Vol. 32 Issue: 2, pp.138-155

Lueptow, L. B., Garovich-Szabo, L., \&Lueptow, M. B. (2001). Social change and the persistence of sex typing: 19741997. Social Forces, 80(1), 1-36.

Lyness, K.S.\&Tompson, D.E. (1997).Above the glass ceiling?A comparison of matched sample of female and male executive.Journal of applied Psychology, 82 (3), 359-375.

Macchiavello, R., Menzel, A., \& Woodruff, C. (2014). Managerial Capital and Productivity: Evidence from a Training Program in the Bangladeshi Garment Sector. IGC Growth Week Presentation, 25.

Mainiero, L. A., \& Sullivan, S. E. (2005). Kaleidoscope careers: An alternate explanation for the "opt-out "revolution. Academy of Management Perspectives, 19(1), 106-123.

Marshall, M. N. (1996). Sampling for qualitative research. Family practice, 13(6), 522-526.
Mathur-Helm, B. (2006). Women and the glass ceiling in South African banks: an illusion or reality? Women in Management Review, 21(4), 311-326.

Merriam, S. B. (2002). Introduction to qualitative research. Qualitative research in practice: Examples for discussion and analysis, 1, 1-17.

Merriam, S. B. (2009). Qualitative research: A guide to design and implementation. San Francisco, CA: John Wiley \& Sons.

Meyerson, D. E., \& Fletcher, J. K. (2000). A modest manifesto for shattering the glass ceiling. Harvard Business Review, 78(1), 126-136.

Meyerson, D. E., \& Fletcher, J. K. (2005). A modest manifesto for shattering the glass ceiling. Harvard Business Review, 78(1), 126-136.

Miles, M. B., \&Huberman, A. M. (1984). Drawing valid meaning from qualitative data: Toward a shared craft. Educational researcher, 13(5), 2030.

Miles, M. B., Huberman, A. M., Huberman, M. A., \&Huberman, M. (1994). Qualitative data analysis: An expanded sourcebook. sage.

Morehouse, R. E., \&Maykut, P. (2002). Beginning qualitative research: A philosophical and practical guide.Routledge.

Morrison, A. M., \& Von Glinow, M. A. (1980). Women and minorities in management (Vol. 45, No. 2, p. 200).American Psychological Association.

Morrison, A. M., White R. P., Van Velsor E. \& The Center for Creative Leadership. (1987).Breaking the Glass ceiling: Can women reach the top of 
America's largest corporations? Reading, MA; addisonwesley

Morrison, A. M., White, R. P., White, R. P., \& Van Velsor, E. (1987). Breaking The Glass ceiling: Can Women Reach The Top Of America's

Largestcorporations?.Pearson

Education.

Moustakas,

C. (1994). Phenomenological research methods.Sage.

Omar, A. \& Davidson, M.J. (2001). Women in management: A comparative cross-cultural overview. Cross Cultural Management, 8(3/4), 35-97.

Pai, K., \& Vaidya, S. (2009). Glass ceiling: role of women in the corporate world. Competitiveness review: An international business journal, 19(2), 106-113.

Parliament of the democratic socialist republic of srilanka.Tertiary and vocational education (amendment) act, no. 50 of 1999.Retrieved from http://www.tvec.gov.lk/wpcontent/uploads/2017/03/Act_No_50_o f_1999.pdf.

Paruntu, A. A., \&Pandowo, M. (2018). The influence of glass ceiling practices to women employe in bank sulutgo branch bitung. Jurnal EMBA: JurnalRisetEkonomi, Manajemen, BisnisdanAkuntansi, 6(2).

Patton, M. Q. (1990). Qualitative evaluation and research methods. SAGE Publications, inc.

Patton, M. Q. (2002). Two decades of developments in qualitative inquiry: A personal, experiential perspective. Qualitative social work, 1(3), 261-283.
Paulina Salinas, Gianni Romaní, (2014) "Gender barriers in Chilean mining: a strategic management", Academia RevistaLatinoamericana de Administración, Vol. 27 Issue: 1, pp.92107

Polachek, S. W. (1981). Occupational self-selection: A human capital approach to sex differences in occupational structure. The review of Economics and Statistics, 60-69.

Polit, D. F., \&Hungler, B. P. (1991).Nursing Research Principles and Methods 4th edn JB Lippincott.

Ponnuswamy, I., \& Lysander Manohar, H. (2014). Breaking the Glass ceiling-A Mixed Methods Study Using Watkins and Marsick's Learning Organisation Culture Model. Asian Women, 30(3).

Qu, S. Q., \&Dumay, J. (2011).The qualitative research interview. Qualitative research in accounting \& management, 8(3), 238264.

Rai, U. K., \& Srivastava, D. (2010). Women executives and the glass ceiling: Myths and mysteries from Razia Sultana to Hillary Clinton.

Remington, J., \&Kitterlin-Lynch, M. (2018).Still pounding on the glass ceiling: A study of female leaders in hospitality, travel, and tourism management. Journal of Human Resources in Hospitality \& Tourism, 17(1), 22-37.

RincónDiez, V., González, M., \&Barrero, K. (2017). Women and leadership: Gender barriers to senior management positions. Intangible Capital, 13(2), 319-386.

Rowley, C. \&Yukongdi, V. (2009).The Changing Face of Women Managers in Asia. London: Routledge. 
Saadin, I., Ramli, K., Johari, H., \&Harin, N. A. (2016). Women and Barriers for Upward Career Advancement-A Survey at Perak State Secretariat, Ipoh, Perak. Procedia Economics and Finance, 35, 574-581.

Saleem, S., Rafiq, A., \&Yusaf, S. (2017). Investigating the glass ceiling phenomenon: An empirical study of glass ceiling's effects on selectionpromotion and female effectiveness. South Asian Journal of Business Studies, 6(3), 297-313.

Salinas, P., \& Romani, G. (2014). Gender barriers in Chilean mining: a strategic management. Academia RevistaLatinoamericana de Administración, 27(1), 92-107.

Sanders, P. (1982). Phenomenology: A new way of viewing organizational research. Academy of management review, 7(3), 353-360.

Scandura, T. A. (1992). Mentorship and career mobility: An empirical investigation. Journal of organizational behavior, 13(2), 169-174.

Schneer, J. A., \& Reitman, F. (2002). Managerial life without a wife: Family structure and managerial career success. Journal of Business Ethics, 37(1), 25-38.

Simpson, R., \& Altman, Y. (2000). The time bounded glass ceiling and young women managers: career progress and career success-evidence from the UK. Journal of European Industrial Training, 24(2/3/4), 190-198.

Singh, V., \&Vinnicombe, S. (2004). Why so few women directors in top UK boardrooms? Evidence and theoretical explanations. Corporate Governance: An International Review, 12(4), 479488.
Smith, P., Caputi, P., \& Crittenden, N. (2012). How are women's glass ceiling beliefs related to career success?. Career Development International, 17(5), 458-474.

Smith, P., Caputi, P., \& Crittenden, N. (2012). How are women's glass ceiling beliefs related to career success?. Career Development International, 17(5), 458-474.

Sparkes, A. C., \& Smith, B. (2009).Judging the quality of qualitative inquiry: Criteriology and relativism in action. Psychology of sport and exercise, 10(5), 491-497.

Sri Lanka directors institute ,2017. Sri Lankan directors report 2017 Retrieve from

http://www.slid.lk/sites/default/files/A nnual\%20Report\%202018.pdf

Stahl, M. L., Ferenz, C. R., Kelleher, K. L., Kriz, R. W., \& Knopf, J. L. (1988). Sequence similarity of phospholipase C with the non-catalytic region of src. Nature, 332(6161), 269.

Sundaram, V. (2018). A continuum of acceptability: understanding young people's views on gender based violence. Gender based violence in university communities: Policy, prevention and educational interventions.

Tashakkori, A., \& Creswell, J. W. (2007).The new era of mixed methods.

Tlaiss, H., \&Kauser, S. (2010). Perceived organizational barriers to women's career advancement in Lebanon. Gender in Management: An International Journal, 25(6), 462-496.

True, J. (2012). The political economy of violence against women.Oxford University Press. 
U.S Department of Labor.(1991) Glass ceiling Final Report - US Department of labor 1991.Retrievedfrom https://www.dol.gov/oasam/programs/ history/reich/reports/ceiling2.pdf.

UnitedStates Equal Employment Opportunity Commission (2011) Retrieved from https://www.eeoc.gov/federal/reports/f sp2011/upload/FY-2011-AnnualReport-Part-IMaster.pdf

Wage Indicator Foundation.(2017) Wages in context in the garment industry in Asia 2017.Retrievedfromhttps://wageindicat or.org/documents/publicationslist/publi cations-2016/van-klaveren-m-2016wages-in-context-in-the-garmentindustry-in-asia-amsterdamwageindicator-foundation-april-282016.

Weyer, B. (2007). Twenty years later: explaining the persistence of the glass ceiling for women leaders. Women in Management Review, 22(6), 482-496.

Wilson, E. (2014). Diversity, culture and the glass ceiling. Journal of Cultural Diversity, 21(3), 83.

Wirth, L. (2001). Breaking through the glass ceiling.Women in management.

Wirth, L. (2004). Breaking Through the Glass ceiling: Women in Management. 2004 Update. International Labour Office.

Wood, D. F. (2009).Barriers to women's leadership in faith-based colleges and universities. Women in academic leadership: Professional strategies, personal choices, 74-94.

Woodard, N., \& Saini, D. S. (2006). Diversity management issues in USA and India: Some emerging perspectives.
Woods, N. F., \& Catanzaro, M. (1988). Nursing research: Theory and practice (pp. 438-9). St. Louis: Mosby.

Worrall, L., Harris, K., Stewart, R., Thomas, A., \& McDermott, P. (2010).Barriers to women in the UK construction industry. Engineering, Construction and Architectural Management, 17(3), 268-281.

Wright, L. (1994). CrockettTellei,"Women in Management in Indonesia". Competetive Frontiers, WomenManagersin a GlobalEconomy, Cambridge, Massachussets, Blackwell Publishers.

Yin, R. K. (2015). Qualitative research from start to finish.Guilford Publications.

Yukongdi, V. \& Benson, J. (2005). Women in Asian management: Cracking the glass ceiling. Asia Pacific Business Review, 11(2), 139-148.

Zafarullah, H. (2000). Through the brick wall, and the glass ceiling: Women in the civil service in Bangladesh. Gender, Work \& Organization, 7(3), 197-209 